\title{
INTERNATIONAL BANKING: ITS ROLE IN FLORIDA'S ECONOMY AT THE OUTSET OF THE TWENTY-FIRST CENTURY
}

\author{
Emmanuel N. Roussakis \\ FLORIDA INTERNATIONAL UNIVERSITY
}

Dimitrios D. Thomakos

FLORIDA INTERNATIONAL UNIVERSITY

0 ne of the most remarkable economic developments of the 1970s for the State of Florida was its emergence in the international financial world. Florida's economy, which until then was essentially relying on tourism, agriculture and the construction industry, began during the 1970 s to gradually acquire a new dimension- international banking. Florida's proximity to Central and South American markets, its bilingual population, and the promulgation by the state of international banking legislation have all contributed to Miami's emergence -both nationally and internationally- as a specialized Latin American banking center.

With international banking a major financial activity, its impact is felt throughout the Florida economy. Employment and office expenditures have a direct effect on local income. However, the total economic impact of international banking activities on the local economy is even more important when the multiplier effect of all direct and indirect expenditures associated with international banking is factored in. The purpose of this study is to describe the size and composition of international banking activities in Miami and to identify the effects of these activities for MiamiDade County and, more broadly, for the Florida economy. To quantify this information a survey was undertaken in February 2000 among banking institutions in Miami-Dade*. Although other financial institutions, such as security firms, provide international services, this survey was limited to commercial banks and Edge Act corporations. The results are presented in the body of this report ${ }^{1}$.

* The authors want to express their appreciation to Florida International Bankers Association, Inc. (FIBA) for its assistance and support with the survey of international institutions.

1 A survey was conducted among 106 banking institutions to collect information non-publicly or not readily available. Questionnaires were prepared and mailed to these institutions and their responses were used in preparing the results of the present study. 


\section{MIAMI'S INTERNATIONAL BANKING COMMUNITY}

Over the last three decades an increased number of banking institutions have established international operations in Miami. Based on their legal designations, three second category. The last category included U.S. insured commercial banks with foreign assets -that is, commercial banks headquartered within Miami-Dade and banks domiciled outside Miami-Dade with local branches in multiple locations. These categories combined accounted for 102 active international offices at yearend 1999.

The total number of institutions and the institutional composition of each of the individual categories have changed over time. For example, ten years earlier (year-end 1989) Miami's international banking community included about the same number of foreign bank offices, a larger number of Edge Act corporations, about the same number of commercial banks and no local branches of out-state banks due to the absence of federal interstate branching legislation ${ }^{2}$. The forces responsible for the ensuing changes included the consolidation of the banking industry in the United States and abroad and the enactment of federal legislation (Foreign Bank Supervision Enhancement Act of 1991) that tightened the requirements for the establishment and continued

2 In 1989 there were 54 offices of foreign banks, 27 Edge Act corporations and 25 commercial banks with foreign departments, making the total number of internationally active institutions 107 . See Robert Grosse, The Economic Impact of International Banking in Florida, 4th Survey, sponsored by Florida International Bankers Association, November 22, 1990. existence of foreign banks in the United States. Although amendment of this legislation (Economic Growth and Regulatory Paperwork Reduction Act of 1996) eased somewhat these requirements, the end result was that fewer foreign banks opened up in Miami to offset the effects of the consolidation. Thus, the net number of foreign bank offices declined. On the other hand, enactment of federal interstate branching legislation (Interstate Banking and Branching Efficiency Act of 1994) enabled out-of-state banks to establish a less costly local presence and engage in international banking through branches, rather than through separately-capitalized Edge Act corporations.

More important than the change in institutional composition, has been the change in the financial profile of Miami's international banking community. Bank consolidation has resulted in financial institutions with larger asset bases, and greater depth and technical expertise -key ingredients for the capacity to finance large or complicated transactions and to provide sophisticated financial services. Table 1 portrays the active international banking institutions by their legal designation and identifies their corresponding volume of assets that totaled $\$ 44,4$ billion at the end of 1999.

\section{Foreign Banks}

Since the opening of the first foreign bank office in Miami by Israel Discount Bank Ltd. on January 26, 1978, more than 100 foreign banking institutions obtained a state license to operate in Florida. At yearend 1999, 51 active foreign banks operated in the state. In terms of country of origin, 23 institutions came from Europe, 20 from 
the Caribbean, and Central and South America, 5 from Asia and the Middle East, and 3 from North America. The countries with the largest representation were Switzerland, with six institutions, and Spain with five.

1). With the exception of four representative offices, all others operated in the Miami area, with the majority concentrated in the Brickell-downtown financial district. The total assets of the 38 international agencies operating in Miami at year-end 1999 amounted to about \$20 billion. The sin-

Table 1

Institutions Engaged in International Banking and their Related Assets, December 31, 1999

\begin{tabular}{|lrc|}
\hline $\begin{array}{l}\text { Legal Designation of } \\
\text { Institutions }\end{array}$ & $\begin{array}{c}\text { Number } \\
\text { (billions of dollars) }\end{array}$ & $\begin{array}{c}\text { Assets } \\
\text { Foreign Banks } \\
\quad \text { Agencies }\end{array}$ \\
$\quad \begin{aligned} \text { Representative office } \\
\text { Administrative offices }\end{aligned}$ & 12 & 19,6 \\
Edge Act corporations & 6 & \\
U.S. insured commercial banks & 13 & 11,5 \\
Headquartered in Miami-Dade & 27 & \\
Headquartered outside Miami-Dade & 6 & 11,3 \\
Total & 102 & 44,4 \\
\hline
\end{tabular}

Note: A detailed identification of the institutions comprising each of the above categories is provided in Table 3 in the Appendix.

Source: Data on foreign banks are listed in the Division of Banking, State of Florida http: //www.dbf.state.fl.us/intbank.html. Data on Edge Act corporations and Miami-Dade headquartered banks come from the Board of Governors of the Federal Reserve System. Data on branches are derived from the survey conducted for and reported in this report.

gle largest asset item was loans and leases and accounted for $\$ 12,3$ billion or 62,76 percent of total agency assets. The three largest Miami agencies (Barclays, Lloyds TSB, and Dresdner) accounted for 52,21 percent of all agency assets (Division of Banking, State of Florida).

Since 1992, legislation has allowed international banking corporations desiring to establish a physical presence in Florida

These institutions operated through a combination of different legal forms. Based on the number of licenses held, 26 were issued to institutions from Europe, 22 to institutions from the Caribbean and Central and South America, 5 to institutions from Asia and the Middle East, and 3 to institutions from North America.

In terms of type of vehicle used, there were 38 agencies, 12 representative offices and 6 administrative offices (Table to do so through establishment of a branch office. A branch may perform the same functions as domestic institutions and offer a full range of banking services, under the name and legal obligation of the parent bank. Although Florida had previously allowed foreign banks to operate through branches, to date economic considerations have made the agency form the preferred legal vehicle. Enactment of state legislation in 1977 (which predated federal legislation by one year) first authorized 
foreign banks to use the agency and representative office vehicles for carrying out an array of functions. An agency is a legal and operational part of the parent bank with the full resources of that parent behind the local office. An agency does not have its own board of directors or any shares of stock outstanding. Although for managerial and regulatory purposes it maintains its own set of books, its assets and liabilities are in fact those of the parent bank. An agency's permissible activities are of a more limited scope than that of a branch. They include most of the same functions performed by domestic banks, such as extension of loans to foreign residents and business, and domestic loans. However, an agency may not accept deposits from U.S. residents -only from nonresident entities or persons, and interbank deposits. An agency may maintain credit balances (the functional equivalent of deposits) so long as they are associated with international transactions and are self-liquidating (e.g., using up the proceeds of a line of credit). Another limitation is that an agency cannot exercise discretionary fiduciary powers for residents.

An alternative vehicle that has been available to foreign banks for undertaking banking activities in Florida has been the representative office. A representative office cannot conduct general banking activities. It may promote or assist the deposit-taking, lending, or other financial or banking activities of the parent bank. A representative office may serve as a liaison in Florida between the parent bank and its existing and potential customers. It may provide information, advice, and local contacts for the parent bank's business clients and watch over correspondent banking relationships. A key advantage of this legal vehicle is that if the parent bank eventually decides to upgrade its local presence, the existence of a representative office for some prior period usually provides a valuable base of contacts and expertise to facilitate the change.

Present Florida law provides for still another alternative vehicle for foreign banks wishing to undertake banking activities in the state. This includes the administrative office. Introduced in 1983 through enactment of legislation, the administrative office option allows foreign banks to engage in a broader range of activities (mostly, back-office operations) than allowed to a representative office. Specifically, an administrative office may perform such functions as administering personnel and operations; engaging in data processing or record-keeping activities; and negotiating, approving, or servicing loans or extensions of credit and investments.

\section{Edge Act and Agreement Corporations}

Drawing its origin from a 1919 amendment to the Federal Reserve Act, an Edge Act corporations is a domestic subsidiary that may be owned by a U.S. bank or (since enactment of the International Banking Act of 1978) by a foreign bank. The statechartered and -supervised counterpart to an Edge Act corporation is known as an Agreement corporation because it must agree (with the Federal Reserve Board) to similar restrictions to those that govern Edge Act corporations. State supervision has been seen as superfluous and as a result, Edge corporations have emerged as a more recognized and accepted vehicle for the conduct of international banking and financing operations. 
An Edge and Agreement corporation may function as an investment company, taking equity positions in foreign commercial and industrial organizations (investment Edge). Alternatively it may function as a commercial bank accepting deposits and making loans to companies engaging in international business (banking Edge). Investment Edges expand the types of companies in which their parent banks may invest. By law, U.S. banks may invest abroad only in other banking organizations. However an Edge corporation may invest in any type of foreign company, as long as it does not engage in business in the United States, including making any domestic loans. Banking Edges extend the geographic reach of their parents because an Edge was not considered a bank and hence was not subject to the same interstate banking prohibitions. Thus in the 1960s the trend was for banks from outside the state of New York to form banking Edges and locate them in New York City for conducting international banking and for trading in foreign exchange. In the 1970 s and 1980s, the trend was toward expansion into regional financial centers, such as Miami, Chicago, and San Francisco.

Enactment of legislation in the mid1990s providing for the removal of federal interstate branching restrictions undermined the appeal of banking Edges, and their relative importance in international banking has therefore declined. Major disadvantages of a banking Edge, compared with an agency, are the smaller size of its loans (due to its smaller capital base, compared with that of the agency's parent bank) and the limitation of domestic lending ability to international or foreign business transactions. Of the 82 Edge and Agreement corporations in operation at year-end
1999, 27 were banking Edges located mostly in New York and Miami-Dade with total assets of $\$ 18$ billion. Miami-Dade accounted for 13 of these banking Edges, with assets of $\$ 11,5$ billion or 63,9 percent of the total. Most of the assets of MiamiDade Edges were in the form of interest bearing deposits (26,1 percent), securities (21,9 percent), and loans and leases (22,2 percent). The three largest Edges (HSBC Republic International Bank, Citibank International and Banco Santander Central Hispano International) accounted for 81,6 percent of all assets (Board of Governors of the Federal Reserve System).

\section{Commercial Banks}

The presence of Edge Act corporations and foreign banks in Miami has enjoyed significant publicity, over the years, and for obvious reasons. These institutions represent U.S. and foreign banks that are among the largest in the world. Their presence alone is a recognition of Miami's international financial importance. The publicity enjoyed by these institutions has been in apparent contrast to that afforded the offices of the internationally active local or out-of-state commercial banks -another participant in Miami's international banking community. As might be expected, the contribution of domestic banks in the internationalization of Miami has been essentially along traditional lines; gathering foreign deposits and extending trade financing. Miami banks became involved in international banking from the very beginning. Expansion of foreign trade in the early 1970s resulted in increased calls upon the local banking community to finance and facilitate their customers credit needs. Local banks, as elsewhere, were faced with a major decision: should 
such trade financing be directed to their money center correspondents or should they develop their own international expertise. Many local banks, some of regional stature, decided in favor of the latter and proceeded to finance trade directly.

Typically, local banks engaged in international banking may be domesticchartered Miami-Dade-headquartered institutions or branches of in-state or outof-state commercial banks. In either case, they are full-service institutions, offering wholesale and retail services to clients. Many of these institutions formally engage in the provision of international services through international banking departments or through a staff of specialists who offer services related to trade finance-collections, letters of credit, and foreign exchange. A good number of local banks engage in international banking informally by relying on correspondent banks for the provision of international services.

As indicated in Table 1, of the U.S. insured commercial banks headquartered in Miami-Dade at year-end 1999, 27 institutions were reported to hold foreign assets that totaled $\$ 2,0$ billion. The single largest item, international loans, amounted to $\$ 1,7$ billion or 85,8 percent of total foreign assets. The four most active international lenders (Hamilton, Commercebank, Pinebank, and SunTrust) accounted for 66 percent of all foreign assets held by Miami-Dade headquartered banks (Board of Governors of the Federal Reserve System).

Of the insured commercial banks domiciled within or outside Florida and operating in Miami-Dade through local branches, 6 institutions engaged in the provision of international financial services at year-end 1999. Their foreign assets amounted to $\$ 11,3$ billion with foreign loans accounting for the single largest portion, 69,7 percent (survey data).

\section{SCOPE OF SERVICES OFFERED}

The growth of international banking in Miami has been driven by three traditional services -trade financing, loans to banks in foreign countries, and private banking. Table 2 identifies the importance of each of these services as of December 31, 1999.

\section{Trade Financing}

Miami's bilingual population and its geographical proximity to markets in Central and South America has had a pronounced effect in the development of trade with these markets in the 1970s. The role of Miami as the gateway to the Caribbean and Latin America soon led to the emergence of South Florida into a major transshipment point notonly for U.S. exports but also for products from Europe and the Far East. As foreign trade expanded banks have been increasingly called upon to finance and facilitate their customers' needs. Growth of foreign trade and the promulgation by the state of international banking legislation proved instrumental in developing international expertise among local banks and in attracting the establishment of foreign banks and Edge Act corporations in Miami's banking community. Because of their knowledge of Latin markets, economic conditions and foreign companies, these institutions have been a key source of 
Table 2

Value of Traditional Services (millions of dollars)

\begin{tabular}{|c|c|c|c|}
\hline $\begin{array}{l}\text { Legal Designation of } \\
\text { Institutions }\end{array}$ & $\begin{array}{c}\text { Customer } \\
\text { Liabilities } \\
\text { on Acceptances } \\
\text { Outstanding }\end{array}$ & $\begin{array}{l}\text { Loans to Banks in } \\
\text { Foreign Countries }\end{array}$ & $\begin{array}{c}\text { Private Banking } \\
\text { (Foreign Assets } \\
\text { Under } \\
\text { Management) }\end{array}$ \\
\hline Foreign bank agencies & 40,0 & 4422,2 & 8010,0 \\
\hline Edge Act corporations & 14,3 & 40,2 & 13695,3 \\
\hline U.S. insured commercial banks & & & \\
\hline Headquartered in Miami-Dade & 63,1 & 770,0 & 11562,6 \\
\hline $\begin{array}{l}\text { Headquartered outside Miami- } \\
\text { Dade }\end{array}$ & 999,0 & 3256,0 & 5985,1 \\
\hline Total & 1116,4 & 8488,4 & 39253,0 \\
\hline
\end{tabular}

Source: Data on customer liabilities and loans to banks in foreign countries for foreign bank agencies are listed in the Division of Banking, State of Florida http: //www.dbf.state.fl.us/intbank.html. Same data for Edge Act corporations and Miami-Dade headquartered banks come from the Board of Governors of the Federal Reserve System. Same data on branches are derived from the survey conducted for and reported in this report. Data on private banking (foreign assets under management) in all cases are derived from the survey conducted and reported in this report.

import and export financing for U.S. firms. As of December 31, 1999, these institutions held $\$ 1,1$ billion in customer liabilities on acceptances. This amount understates the size of trade financing because a sizable part of such financing is extended in the form of advances to banks in foreign countries. The local branches of commercial banks domiciled within or outside Florida dominated this type of financing (89,5 percent).

Although trade financing has been a core business for Miami banks, recent advances in technology and e-commerce are gradually transforming the way this activity has been carried on. And just as on line trading and other financial transactions conducted through the Internet are affecting the pricing of financial services so will the use of technology in trade financing. Although technology will improve operational efficiency, competitive pressures will eventually impact pricing and in turn decrease the returns that banks realize from this traditional activity.

\section{Loans to Banks in Foreign Countries}

Trade financing has been and still is the core activity for Miami's internationally active banks. In turn the growth of trade financing has stimulated the growth of loans to foreign banks. As Miami institutions became more familiar with the countries with which their customers traded, they began to work regularly with foreign correspondent banks. This in turn created additional profitable international financial opportunities. Extensions of lines of credit to foreign commercial banks thus grew into a significant activity for Miami banks. These loans normally involve less risk and more limited foreign travel than direct loans to nonfinancial foreign firms. As of December 31, 1999, loans to banks in foreign countries amounted to about 
$\$ 8,5$ billion, with most of the financing provided by foreign bank agencies $(52,1$ percent) and local branches of commercial banks domiciled within or outside Florida (38,4 percent).

The recent surge in the acquisition of banks throughout Latin America, reflective to some extent of a global consolidation trend in financial services, will have a significant effect in the future demand of financial services from these banks. Indeed, the acquisition of banks throughout Latin America, traditionally clients of foreign trade financing, by banks from Europe and the United States, will have some effect on the ability of Miami banks to continue providing the same services in the future as in the past.

\section{Private Banking}

Miami banks have evolved over the years from mere deposit-takers to more sophisticated financial-service providers. Growing competition has been a key consideration in this transformation. International private banking -the provision of wealth management services to high net worth individuals and companies in Latin America- has been an ever more attractive market for Miami banks. The relative importance of this activity has prompted some institutions to include it in their international departments, while others have treated it as an integral part of their private banking units. In servicing the financial needs of Latin American clients, banks have provided both traditional and not-so-traditional banking services. These have included:

- Deposit related activities, such as establishing money market accounts, certificates of deposit, and money market funds.

- Extension of credit -personal or corporate.

- Investment management, including custodial services, real estate services, handling investments in precious metals, currencies, commodities, and the provision of financial and tax advice.

Many of the original clients were established wealthy families that sought a high level of confidentiality from Miami banks and a safety net from the oscillating political and economic uncertainties of their home countries. In other cases, wealthy clients sought out private banking services mainly to move their funds abroad and to avoid the scrutiny of domestic regulatory (e.g., exchange control) and tax authorities. The 1990s, however, have witnessed a change in the profile of the private banking clients and the nature of services sought. Increasingly, in recent years, private banking clients have demanded better investment performance and more sophisticated financial services. This shift has been consistent with a global trend and has reflected the surge in firstgeneration riches created out of newly successful businesses. The new breed of private banking clients earned rather than inherited their wealth and usually demands a more active approach to their wealth management as well. Yield and service have thus become additional goals to confidentiality and security.

The relatively stable, high quality profits associated with private banking and the valuable cross-selling opportunities associated with this activity have intensified 
competition in this market. Miami private bankers, much like their colleagues elsewhere, are starting to target a much larger market segment than in the past. They are now seeking the growing group of highincome professionals who may not yet be high net worth according to the standard definition, but are under-served by banking institutions.

A significant factor that may eventually affect the ability of Miami banks to maintain their position in this market in the years ahead are advances in technology. The Internet is globalizing the reach of the individual investors seeking better investment performance and so-phisticated financial services. At year-end 1999, surveyed Miami institutions reported foreign assets under management in the amount of $\$ 39,2$ billion. This amount understates the size of this activity since a good number of local commercial banks have not been included in the survey because they held no foreign assets and yet they actively engaged in the provision of international private banking services. Edge Act corporations accounted for the largest share of this business $(34,9$ percent), followed by Miami-Dade headquartered commercial banks (29,4 percent) and foreign bank agencies (20,4 percent). These data do not reflect the international private banking services of the local offices of security firms, which also engage in this type of activity.

\section{Emerging Trends in Services}

Forces at work are bringing about important changes in the scope of international services offered by Miami banks. Increasing competition from other banks, strengthened bargaining positions from borrowers and other clients, and a growing liberalization in the permitted activities of a bank are typical of these forces. To some banks these forces raise the prospect of decreasing returns from traditional activities. Against this prospect, the improving economic conditions that currently characterize most Latin American countries are creating opportunities for new financing alternatives for the region as a whole. This has been especially true for those Miami institutions that can capitalize on their expertise in the region and strengthen their long-established relationships throughout Latin America. Some banks, for example, have been extending their services to include international factoring. Factoring entails the purchase of loans, with or without recourse, that foreign correspondent banks make to finance commercial customers' exports. These exports originate from companies in Latin America and the Caribbean and are directed to U.S. companies that do business with local international banks. For the foreign correspondents that operate in an environment of high interest rates and low liquidity, factoring offers the benefit of automatically generating funds. For Miami's international banks factoring offers an opportunity to develop a new product.

Other institutions in Miami are gradually shifting the focus of their strategies into promoting more value added products and services, such as providing syndicated credits, project financing, treasury, capital markets and other sophisticated products. One particularly attractive product is credit enhancements (letter-of-credit backing) for commercial paper and other issues in financial markets in Latin America. This practice has led to the transfer of some capital market operations from New York 
and London to Miami to focus on the region, expand banks' product range, improve their quality of service extended to clients, and strengthen their presence and relationships. From their base in Miami they now actively compete with prime name banks in New York and London in the provision of sophisticated financial services to Latin American clients.

As new services and products are introduced, some of the larger types of banking institutions are capitalizing on their Miami base and geographical location to upgrade their operational status into an administrative headquarter for their financial activities in Latin America. In other words, these institutions use their base in Miami for staff support and managerial oversight over the activities of their bank's offices in the Latin American region. The scope of this oversight varies among institutions and may include management of the entire loan portfolio and investment banking services to the Latin American region. Citibank International, Bank of America, Barclays Bank, Dresdner Bank, Banque Nationale de Paris and $\mathrm{ABN}-\mathrm{AMRO}$ are examples of these institutions. Their offices function very similarly to the Latin American regional offices of multinational companies located in Miami-Dade.

\section{QUANTIFYING THE ECONOMIC IMPACT}

Almost all the necessary information for measuring the economic impact of international banking in Florida comes from the survey conducted for this study. We have summarized the survey results in Table 4 in the appendix. The total response rate to the survey was 57,54 percent, with highest response from Branches and Edge Act Corporations (83,33 percent) and lowest response from Representative and Administrative Offices (33,33 percent). The total response rate is higher than the response rate from the last (1989) survey of this type, which was 53 percent $^{3}$.

Using the survey results we have constructed estimates of the international banking population totals for the major areas of economic impact on the local economy: (a) direct income effects from employees and payroll expenses, (b) indirect income effects from non-payroll expenses, such as office expenses, (c) external effects from domestic and foreign clients and bank officials who visit the local offices of their institutions, and (d) taxes and government revenues ${ }^{4}$. Each of these categories significantly influences the economy, and they are the key variables used for computing the direct and indirect income effects of international banking on Florida's economy.

\section{Direct Income Effects: Employment and Earnings}

The estimated total direct employment for 1999 was 5586 employees. This compares to 3655 employees from the last survey, which indicates a decade increase in employment of 52 percent. The estimated total annual payroll expenses for 1999 were about \$ 487541 million, compared

3 Ibid.

4 The estimated banking population totals were constructed from the survey averages. While this is the appropriate method to use it may lead to understating the true population totals. 
to about \$ 121985 million from the last survey, for a decade increase of about $300 \%$. The estimated total employment and payroll figures give us an idea of the direct income effects in the state and local economies from international banking operations. An average increase in employment of 5,2 percent a year contributed to an average increase in generated employee income of 30 percent per year ${ }^{5}$.

\section{Indirect Income Effects: Non-Payroll Expenses}

In addition to the direct income effects from payroll spending, the banking offices made substantial expenditures for other office requirements, such as rent payments, supplies, equipment and maintenance. These expenses produce indirect income effects on the state and local economies, as they constitute direct income for local businesses. The estimated total non-payroll expenses for 1999 were \$ 304805 million that compare to \$ 106 672 million from the last survey, a decade increase of 185 percent. This is equivalent to an average increase of 18,5 percent per year, about two thirds of the annual increase of direct income of 30 percent per year, mentioned in the previous paragraph.

\section{External Effects from Domestic and Foreign Clients and Visiting Bank Officials}

Probably the major external effect from the operation of international banking is

5 The decade change in the Consumer Price Index was about 34 percent so that the increase in income is real and not just nominal. the local spending done by domestic and foreign customers and bank officials who visit the local offices of their institutions. The total number of visitors for 1999 was estimated at about 186770 . This compares to 8880 visitors from the last survey, a decade increase of 2000 percent. This dramatic result demonstrates the attention that local international banking market attracted over the 1990 s. To quantify the indirect expenditure effects that these visitors have for the local economy we "inflated" the estimates of spending per trip given in the last survey. Using the decade increase in the Consumer Price Index (34 percent) we estimated that foreign visitors would spend about \$ 1099 per trip, while domestic visitors would spend about $\$ 789$ per trip. The estimated total amount of visitors' expenses for 1999 was \$ 183251 million. This compares with \$ 53382 million from the last survey, for a decade increase of 243 percent. Note again that this spending is (indirect) income to local businesses, generated by the operation of international banking offices.

\section{Taxes and Government Revenues}

In addition to direct and indirect income effects and external factors, the operation of international banking offices contributes to the state and local government revenues through taxation. The estimated total amount of state and local taxes for 1999 was about \$ 29 million, which compares to just about $\$ 2$ million from the last study. The effect on the state and local economies from such increase in government revenues is not clear, as it depends on the frequently changing expenditure strategies of the local governments. 


\section{Implied Multiplier Effects from Direct and Indirect Income}

The figures of direct (through payroll) and indirect (through office and visitors' expenses) income given above actually understate the magnitude of the economic impact of international banking in Florida. To generate a more complete idea of the total economic impact from these sources, we computed the implied multiplier effects for local consumption and expenditures. We estimated, using quarterly data over the past decade, the aggregate consumption multiplier using (gross) personal income as a measure of aggregate income. The multiplier came out to be 3,125 .

The implied multiplier effects are used to calculate the additional increase in income, through consumption and spending, generated by any given increase in income. This additional impact is calculated as follows:

Implied Multiplier Effect $=$

(Estimated Multiplier - 1) x Generated Income

It follows that the total economic impact is given by the following equation:

Total Economic Impact $=$ Estimated Multiplier $\mathrm{x}$ Generated Income

In Table 4 in the appendix we show both the implied multiplier effects and the total economic impact figures. For total payroll expenses the additional income generated by consumption and spending (i.e. the implied multiplier effect) is estimated to be $\$ 1036$ million (or, over $\$ 1$ billion). This compares to \$ 24397 million from the last survey, an increase of $324 \%$ over the past decade. For nonpayroll expenses, the implied multiplier effect is estimated to be $\$ 647711$ million, which compares to \$ 217578 million from the last survey for an increase of 198 percent over the past decade. Finally, the implied multiplier effect from visitors' expenses is estimated to be $\$ 389408$ million, which compares to \$ 106764 million from the last survey, for a decade increase of about 265 percent.

The total economic impact of international banking in Florida can be computed as the sum of the implied multiplier effects given above plus the direct and indirect figures of income generated by international banking operations. For 1999 we estimated it to be $\$ 3048,741$ million (over $\$ 3$ billion). This figure compares to a total economic impact of $\$ 852,468$ million from the last survey, for an increase over the past decade of 257 percent, or an annual average increase of 25,7 percent. This figure reflects only the impact of commercial and Edge banks and not the contributions from the local offices of security firms, which have recently become substantial participants in Miami's international financial community.

\section{CONCLUSION}

The 21 st century promises to bring new challenges and opportunities and most certainly fundamental changes to the way international banking is done in Florida. New technologies, changes in legislation, mergers and acquisitions, the prospect of the Free Trade Area of the Americas, and the general move toward a global economy will be among the major forces driving this change. The institutional composition will continue to evolve but international banking will remain an important part of Florida's economic profile as evidenced by the fact that the industry contributed 
\$ 30 billion to the state economy last year. The prognosis is therefore strong that international banking will constitute a growing portion of Miami's financial industry and that Miami itself will become an increasingly sophisticated international financial center. 


\section{APPENDIX}

Table 3

Miami-Dade Institutions Engaged in International Banking at Year-end 1999

Insured Commercial Banks with Foreign Assets

Miami-Dade Headquartered Commercial Banks

Hamilton Bank NA

Ocean Bank

Executive National Bank

Gulf Bank

Great Eastern Bank of Florida

Terrabank, NA

Totalbank

City National Bank of Florida

Metro Bank of Dade County

Mellon United National Bank

Hemisphere National Bank

Pacific National Bank

Transatlantic Bank

Commercebank, NA

Continental National Bank of Miami

Delta National Bank and Trust Co. of Florida

Northern Trust Bank of Florida, NA

SunTrust Bank Miami, NA

International Bank of Miami, NA

Pinebank, NA

Intercredit Bank, NA

BAC Florida Bank

Eastern National Bank

Eagle National Bank of Miami

International Finance Bank

Espirito Santo Bank

Commercial Banks Domiciled Outside Miami-Dade that Operate with

Local Branches in Multiple Locations

Bank of America

First Union

Union Planters

Colonial Bank

Citibank

BankAtlantic (savings bank) 


\section{Edge and Agreement Corporations}

American Express Bank International

Banco de Bogota International Corporation

Banco Santander Central Hispano International

Bancafe International

Bankers Trust International PBC

Citibank International

Coutts (USA) International

IBJ Schroder International Bank

HSBC Republic International Bank (Miami)

Riggs International Banking Corp.

Santander Global Bank USA

Banco Latino International

Bank of Boston International

\section{Foreign Banks}

\section{Agencies}

ABN AMRO Bank, NV.

American Express Bank, Ltd

Argentaria Caja Postal y Banco Hipotecario, S.A.

Atlantic Security Bank

Bancaja

Banco Atlantico, S.A.

Banco Bilbao Vizcaya, S.A.

Banco Colpatria

Banco de Credito y Inversiones, S.A.

Banco de Chile

Banco de Sabadell

Banco de La Nacion Argentina

Banco del Pichincha C.A.

Banco do Brazil, S.A.

Banco do Estado do Sao Paulo, S.A.

Banco Ganadero

Banco Industrial de Venezuela, C.A.

Banco Internacional de Costa Rica, S.A.

Banco Mercantil, S.A.C.A.

Banco Portugues do Atlantico

Banco Santa Cruz

Banco Santander Central Hispano, S.A.

Banco Standard Chartered

Banco Union, S.A.C.A

Bank Hapoalim, B.M.

Bank Leumi Le-Israel, B.M.

Bank of Tokyo-Mitsubishi, Ltd.

Banque Nationale de Paris

\section{Country}

The Netherlands

USA

Spain

Cayman Islands

Spain

Spain

Spain

Colombia

Chile

Chile

Spain

Argentina

Ecuador

Brazil

Brazil

Colombia

Venezuela

Costa Rica

Venezuela

Portugal

Bolivia

Spain

Peru

Venezuela

Israel

Israel

Japan

France 
Banque Sudameris

Barclays Bank, PLC

Citizens Bank Ltd

Credit Lyonnais

Dresdner Bank Lateinamerika, A.G.

Israel Discount Bank Limited

Lloyds TSB Bank PLC

Royal Bank of Canada

Standard Chartered Bank

UBS AG

\section{Representative Offices}

Banco Bandeirantes, S.A.

Banco General (Overseas), Inc.

Bank Julius Baer Company, Ltd.

Bank of Scotland

Bank Von Ernst \& Co. Ltd.

Banque Audi Suisse, S.A.

CBG-Compagnie Bancaire Geneve

Credit Suisse

Dresdner Bank AG

Merill Lynch Bank \& Trust Co. (Cayman) Ltd.

National Bank of Canada

The British Linen Bank Ltd.

\section{Administrative Offices}

ABN-AMRO Bank, NV

Banco Standard Chartered

Bank Hapoalim, B.M.

Credit Suisse

Merrill Lynch Bank \& Trust Co. (Cayman) Ltd.

Unibanco, S.A.

\author{
France \\ United Kingdom \\ Jamaica \\ France \\ Germany \\ Israel \\ United Kingdom \\ Canada \\ England \\ Switzerland \\ Country \\ Brazil \\ Cayman Islands \\ Switzerland \\ Scotland \\ Switzerland \\ Switzerland \\ Switzerland \\ Switzerland \\ Germany \\ Cayman Islands \\ Canada \\ England \\ Country \\ The Netherlands \\ Peru \\ Israel \\ Switzerland \\ Cayman Islands \\ Brazil
}

Note: Names of institutions appear as reported at year-end 1999. Subsequent changes in names or licenses are not reflected in this Table.

Several of the institutions present in the local market operated through a combination of different legal forms. For example, American Express operated through an Edge Act corporation and an agency, Dresdner Bank through an agency and a representative office, Credit Suisse through a representative office and an administrative office. This accounts for the appearance of some institutions in more than one category. 


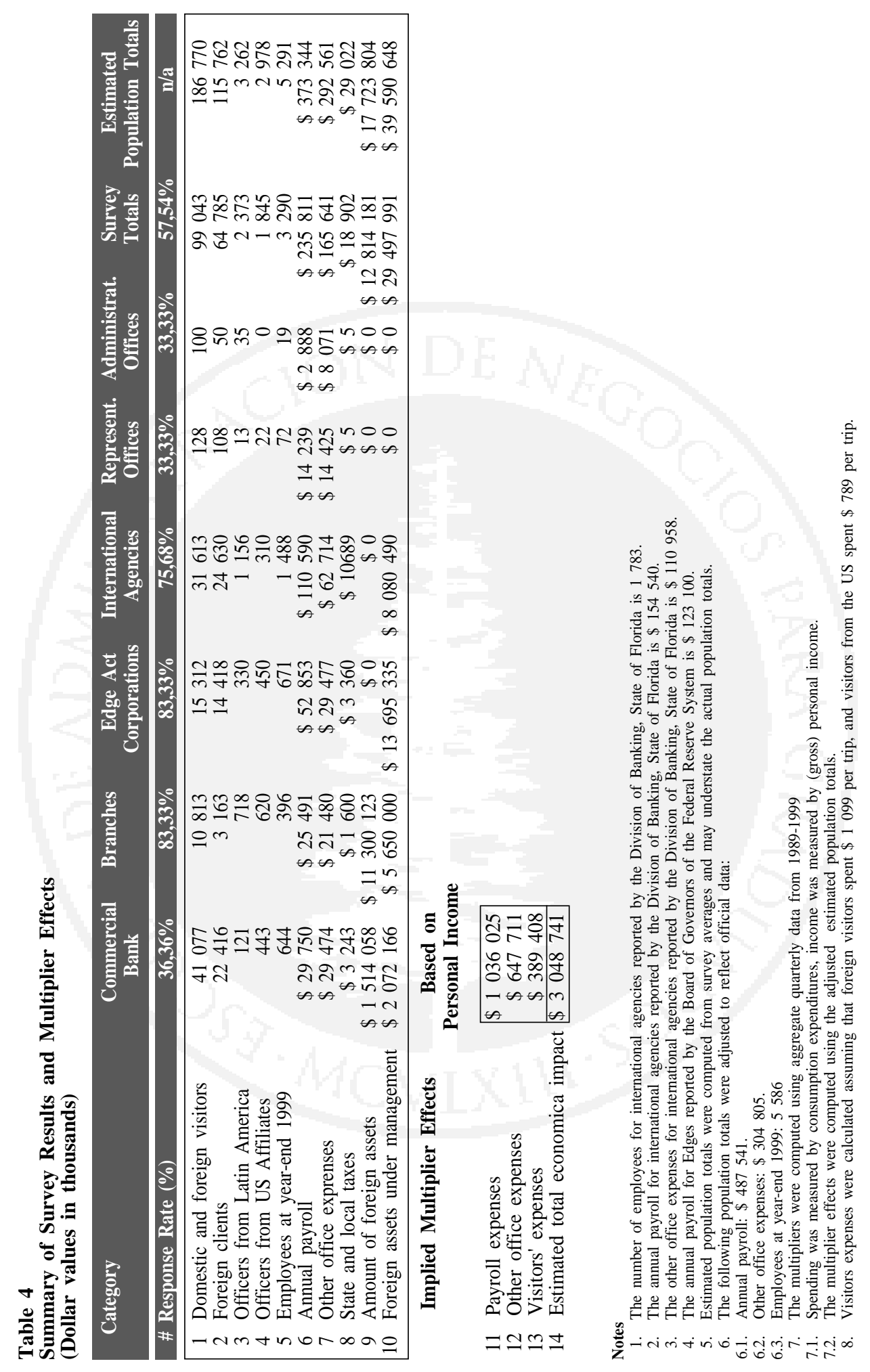

